\title{
Effect of Foliar Application of Manganese and Potassium on Rust Susceptible and Resistant Soybean Genotypes
}

\author{
S.S. Akshatha* and R.V. Koti \\ Department of Crop Physiology, University of Agricultural sciences, \\ Dharwad-580005, Karnataka, India \\ *Corresponding author
}

\section{A B S T R A C T}

\section{Keywords \\ Soybean, $\mathrm{MnSO}_{4}$, Soybean rust, Phakopsora pachyrhizi}

\section{Article Info}

Accepted: 08 June 2018 Available Online: 10 July 2018
An attempt has been made to study the effect of manganese sulphate and potassium silicate on rust incidence, yield and yield components of rust susceptible and resistant soybean genotypes. The results revealed that the Asian soybean rust (ASR) severity was significantly reduced on plants sprayed with manganese sulphate in comparison to plants sprayed with potassium silicate and control. Leaf manganese and potassium contents increased significantly with the application of manganese and potassium. Resistant genotypes had 46 per cent higher leaf manganese content than in the susceptible genotypes. Manganese not only reduced rust but also improved plant height and number of branches and seed yield. In conclusion, manganese sulphate alone was more effective than potassium silicate and their combinations. Rust resistant soybean genotype DSb 23-2 was better against rust giving highest yield as compared to rest of the susceptible and resistant genotypes.

\section{Introduction}

Soybean [Glycine max (L.) Merrill] which has been referred as 'Gold from the Soil' (Piper, 1914) continues to attract the epithets like 'golden bean', 'miracle bean', crop of the planet, 'Cindrella crop', 'wonder bean', functional food of the century etc. Due to its high protein content (38-40\%) besides high oil content (18-20\%), that is "Two in one crop" has gained considerable importance in the agricultural economy of the country (Hegde, 2001). Soybean seed is also rich in minerals $(\mathrm{Ca}, \mathrm{Mg}, \mathrm{P}$ and $\mathrm{Fe}$ ) and vitamins (A, $\mathrm{B}$ and $\mathrm{D})$.
Biotic stresses such as pathogens, insects and weeds can cause negative impacts on its production. Asian soybean rust (ASR) caused by Phakopsora pachyrhizi is the most destructive and over 80 per cent losses are common when environmental conditions are conducive to disease development (Hartman $e t$ al., 1991). The infected plants undergo defoliation and early maturation, which causes reduction in weight and quality of the seeds. Yield losses from soybean rust are associated with reduced photosynthetic activity which is caused by a reduction in canopy green leaf area through the formation of rust lesions, and premature defoliation, which results in less 
dry matter accumulation and reduced harvest index (Kumudini, 2008). The Asian soybean rust (ASR) caused by Phakopsora pachyrhizi, can be controlled using hexaconazole. But it is not environmental friendly. Hence, either developing resistant genotypes to rust or environmental friendly control of disease are better options. Mineral elements are directly involved in some mechanisms of defense as integral components of cells substrates enzymes and electron carriers or as activators, inhibitors and regulators of metabolism. Nutrients are important for growth and development of plants and also microorganisms and they are important factors in disease control (Agrios, 2005).

Manganese has an important role in lignin biosynthesis, phenol biosynthesis, and photosynthesis. Manganese controls lignin and suberin biosynthesis through activation of several enzymes of the shikimic acid and phenylpropanoid pathways (Marschner, 1995). Both lignin and suberin are important biochemical barriers to fungal pathogen invasion (Vidhyasekaran, 2004), since they are phenolic polymers resistant to enzymatic degradation. Hema (2001) and Sanjana et al., (2005) have observed lower rust disease incidence in soybean due to foliar application of $\mathrm{MnSO}_{4}$ in the transition trait of Dharwad. To increase the efficacy of manganese in control of rust, potassium in the form of $\mathrm{K}_{2} \mathrm{SiO}_{3}$ also has been used. Here, an attempt has been made to study whether the disease could be controlled or reduced with the combined application of manganese and potassium and also whether yield can also be increased in both susceptible and resistance soybean genotypes.

\section{Materials and Methods}

The field experiment was conducted during kharif 2016 at Main Agricultural Research Station, University of Agricultural Sciences,
Dharwad. The experiment was comprised of two susceptible soybean genotypes viz., JS $335\left(\mathrm{G}_{1}\right)$ and Kalitur $\left(\mathrm{G}_{2}\right)$ and three resistant genotypes, DSb $21\left(\mathrm{G}_{3}\right)$, DSb 23-2 $\left(\mathrm{G}_{4}\right)$ and EC $241778\left(\mathrm{G}_{5}\right)$ with four treatments viz., nutrient spray of manganese sulphate @ 0.3 per cent $\left(\mathrm{T}_{1}\right)$, potassium silicate @ 0.3 per cent $\left(T_{2}\right)$, combined application of manganese sulphate@ 0.3 per cent and potassium silicate @ 0.3 per cent $\left(\mathrm{T}_{3}\right)$ and control $\left(\mathrm{T}_{4}\right)$ The experiment was laid out in randomized block design with factorial concept with three replications. The treatments were imposed at 40 DAS in the form of foliar spray. The disease intensity was assessed at 55 DAS and 75 DAS by following 0-9 scale of Mayee and Datar (1986) and these scales were converted to percent disease index (PDI) using the formula given by Wheeler (1969). Plant height and number of branches were recorded at 60 DAS. Yield and yield components were recorded at harvest.

$\mathrm{PDI}=$

Sum of numerical disease ratings $\quad 100$

No. of plants

observed

Maximum disease grade

Leaf manganese content $\left(\mathrm{mg} \mathrm{kg}{ }^{-1}\right)$ in the aliquot of plant digest extract and potassium content $(\%)$ in the di-acid plant digest samples were estimated by using atomic absorption spectrophotometer (AAS) and by flame photometer method (Tandon, 1998).

\section{Results and Discussion}

The rust disease appeared naturally during July 2016 as small greyish or brown colored lesions on the lower surface of bottom leaves which further spread to top leaves affecting the normal growth and development till maturity of susceptible genotypes viz., JS 335 
and Kalitur, but same symptoms were not appeared significantly in resistant genotypes. The data on PDI presented in Table 1 indicated that the genotypes and treatments differed significantly at 55 DAS and 75 DAS. The rust disease appeared with the initiation of flowering and spread gradually towards maturity of the crop. In the present investigation, application of manganese sulphate alone recorded significantly lower PDI (11.4) which was followed by potassium silicate (13.9). Significantly higher PDI was observed in the control (15.8) at 55 DAS. At 75 DAS, also the foliar application of manganese sulphate at 0.3 per cent alone recorded showed lower PDI (29.6) followed by the combined application of manganese sulphate and potassium silicate (32.1). Whereas significantly higher PDI was noticed in the treatment of potassium silicate (33.0). Manganese application alone was found superior than potassium silicate alone or in combination with manganese. Sanjana et al., (2005) also has observed lower disease incidence of rust in soybean due to the application of manganese; Graham and Rovira (1984) reported the role of manganese in the resistance of wheat plants to take all disease and found that manganese may be toxic to saprophytic survival of the fungus or may be due to its antioxidant activity against free radicals released during disease infestation.

Among the genotypes, the genotype, EC 241778 recorded significantly lower PDI (0.44 and 3.5) followed by the genotype DSb 23-2 (0.66 and 3.6) at 55 and 75 DAS respectively. Kalitur (34.31) and JS 335 (76.37) were found susceptible with the higher PDI. Interaction effect between treatments and the genotypes differed significantly at 55 DAS. At 55 DAS, the genotype EC-241778 with the combined application of manganese sulphate and potassium silicate the recorded significantly lower PDI (0.27) which was followed by DSb232 with the treatment manganese sulphate
(0.35). Significantly higher PDI was recorded in EC-241778 in the control (38.54).

Morphological characters viz., plant height and number of branches with respect to the genotypes and different treatments differed significantly (Table 1). The foliar application of manganese sulphate at 0.3 per cent recorded significantly maximum height $(62.99 \mathrm{~cm})$ which was followed by the treatment potassium silicate (61.83). Manganese sulphate alone and combination of manganese sulphate and potassium silicate treated plants showed more height. It may be attributed to the lower IAA oxidase activity at higher manganese concentration (Morgan et al., 1976) perhaps lead to more height in the manganese sprayed plants in the present investigation. The results of present studies are in agreement with the Singh et al., (1988) in groundnut who has reported similar effect of increase in height with the application of manganese.

Application of manganese sulphate recorded significantly higher number of branches (8.80) which was on par with potassium silicate (8.53). Similar increase in branches with the application of manganese and potassium in different crops are reported.

Brist and Tripathi (1987) found that decreased safflower growth with manganese deficiency. Similarly, among the genotypes, the number of branches per plant differed significantly at 60 DAS. Significantly higher number of branches were recorded in the genotype DSb 23-2 (8.88) followed by the genotype EC 241778 (8.37) and least number of branches was recorded in genotype JS 335 (7.57).

Manganese content of 20-300 ppm and potassium of 1- 5 per cent are sufficient for growth of various plant species (Jones, 1998). 
Table.1 Influence of nutrients on per cent disease index (PDI), plant height, number of branches, leaf $\mathrm{K}$ and Mn contents of rust susceptible and resistant soybean genotypes

\begin{tabular}{|c|c|c|c|c|c|c|}
\hline \multirow{2}{*}{ Treatment } & \multicolumn{2}{|c|}{ PDI (\%) } & \multirow{2}{*}{$\begin{array}{c}\text { Plant } \\
\text { height } \\
\text { (cm) }\end{array}$} & \multirow{2}{*}{$\begin{array}{l}\text { No. of } \\
\text { branches } \\
\text { (No) } \\
\text { 60 DAS }\end{array}$} & \multirow{2}{*}{$\begin{array}{c}\text { Leaf K } \\
(\%)\end{array}$} & \multirow{2}{*}{$\begin{array}{c}\text { Leaf Mn } \\
\quad(\mathrm{ppm})\end{array}$} \\
\hline & 55 DAS & 75 DAS & & & & \\
\hline $\mathrm{MnSO}_{4} @ 0.3 \%\left(\mathrm{~T}_{1}\right)$ & $11.39(14.80)^{\mathfrak{C} *}$ & $29.57(28.46)^{b}$ & $62.99^{\mathrm{a}}$ & $8.80^{\mathrm{a}}$ & $3.18^{\mathrm{c}}$ & $213.13^{\mathrm{a}}$ \\
\hline $\mathrm{K}_{2} \mathrm{SiO}_{3} @ 0.3 \%\left(\mathrm{~T}_{2}\right)$ & $13.87(16.84)^{\mathrm{b}}$ & $33.03(31.07)^{\mathrm{a}}$ & $61.83^{\mathrm{ab}}$ & $8.53^{\mathrm{a}}$ & $3.95^{\mathrm{a}}$ & $80.07^{\mathrm{c}}$ \\
\hline $\begin{array}{l}\mathrm{MnSO}_{4}+\mathrm{K}_{2} \mathrm{SiO}_{3} @ 0.3 \\
\% \operatorname{each}\left(\mathrm{T}_{3}\right)\end{array}$ & $14.95(17.84)^{\mathrm{b}}$ & $32.07(30.57)^{\mathrm{a}}$ & $59.45^{\mathrm{b}}$ & $8.10^{\mathrm{ab}}$ & $3.64^{b}$ & $193.80^{b}$ \\
\hline Control $\left(\mathbf{T}_{4}\right)$ & $15.83(18.57)^{\mathrm{a}}$ & $32.37(31.07)^{\mathrm{a}}$ & $58.68^{\mathrm{b}}$ & $7.59^{\mathrm{b}}$ & $2.83^{\mathrm{d}}$ & $70.60^{c}$ \\
\hline S. Em \pm & 0.33 & 0.54 & 1.17 & 0.24 & 0.05 & 4.90 \\
\hline LSD@ 5\% & 0.96 & 1.55 & 3.35 & 0.69 & 0.15 & 14.02 \\
\hline \multicolumn{7}{|l|}{ Genotypes (G) } \\
\hline $\operatorname{JS~} 335\left(G_{1}\right)$ & $33.80(35.49)^{\mathrm{a}}$ & $76.37(61.00)^{\mathrm{a}}$ & $60.13^{b}$ & $7.57^{\mathrm{b}}$ & 3.43 & $110.17^{b}$ \\
\hline Kalitur( $\left(\mathbf{G}_{2}\right)$ & $34.31(35.79)^{b}$ & $71.79(58.01)^{\mathrm{c}}$ & $64.49^{\mathrm{a}}$ & $8.09^{\mathrm{ab}}$ & 3.53 & $108.33^{b}$ \\
\hline DSb $21\left(G_{3}\right)$ & $0.87(5.23)^{\mathrm{a}}$ & $3.60(10.91)^{b}$ & $59.60^{\mathrm{b}}$ & $8.35^{\mathrm{ab}}$ & 3.40 & $156.92^{\mathrm{a}}$ \\
\hline DSb $23-2\left(G_{4}\right)$ & $0.66(4.55)^{\mathrm{bc}}$ & $3.57(10.85)^{\mathrm{c}}$ & $58.49^{\mathrm{b}}$ & $8.88^{\mathrm{a}}$ & 3.32 & $159.50^{\mathrm{a}}$ \\
\hline $\operatorname{EC~} 241778\left(G_{5}\right)$ & $0.40(3.54)^{c}$ & $3.47(10.69)^{c}$ & $60.98^{\mathrm{ab}}$ & $8.37^{\mathrm{ab}}$ & 3.32 & $162.08^{\mathrm{a}}$ \\
\hline S. Em \pm & 0.37 & 0.60 & 1.31 & 0.27 & 0.06 & 5.47 \\
\hline LSD@ 5\% & 1.07 & 1.73 & 3.75 & 0.77 & NS & 15.67 \\
\hline \multicolumn{7}{|l|}{ Interaction (T X G) } \\
\hline $\mathbf{T}_{1} \mathbf{G}_{1}$ & $27.72(31.75)^{d}$ & $69.12(56.23)^{\mathrm{c}}$ & 60.57 & $7.94^{\mathrm{cd}}$ & 3.05 & $183.00^{\mathrm{de}}$ \\
\hline $\mathbf{T}_{1} \mathbf{G}_{2}$ & $28.15(32.00)^{\mathrm{fg}}$ & $70.08(56.82)^{d}$ & 68.64 & $10.29^{\mathrm{a}}$ & 3.38 & $167.00^{\mathrm{ef}}$ \\
\hline $\mathbf{T}_{1} \mathbf{G}_{3}$ & $0.44(3.81)^{\mathrm{d}}$ & $2.84(9.69)^{\mathrm{c}}$ & 61.96 & $8.68^{\mathrm{a}-\mathrm{d}}$ & 3.07 & $272.67^{\mathrm{a}}$ \\
\hline $\mathbf{T}_{1} \mathbf{G}_{4}$ & $0.35(3.36)^{\mathrm{fg}}$ & $2.86(9.72)^{d}$ & 61.46 & $8.32^{b-d}$ & 3.32 & $210.00^{b-d}$ \\
\hline $\mathbf{T}_{1} \mathbf{G}_{5}$ & $0.29(3.05)^{\mathrm{g}}$ & $2.94(9.84)^{d}$ & 62.34 & $8.75^{\mathrm{a}-\mathrm{d}}$ & 3.07 & $233.00^{b c}$ \\
\hline $\mathbf{T}_{2} \mathbf{G}_{1}$ & $33.42(35.30)^{\mathrm{c}}$ & $79.09(62.77)^{\mathrm{a}}$ & 59.92 & $8.12^{b-d}$ & 3.99 & $67.00^{\mathrm{g}-\mathrm{i}}$ \\
\hline $\mathbf{T}_{2} \mathbf{G}_{2}$ & $34.10(35.71)^{\mathrm{e}-\mathrm{g}}$ & $75.75(60.57)^{d}$ & 64.74 & $8.49^{b-d}$ & 4.12 & $68.00^{\mathrm{g}-\mathrm{i}}$ \\
\hline $\mathbf{T}_{2} \mathbf{G}_{3}$ & $0.76(4.94)^{b c}$ & $3.58(10.90)^{\mathrm{ab}}$ & 59.80 & $7.60^{d}$ & 3.98 & $80.67^{\text {gh }}$ \\
\hline $\mathbf{T}_{2} \mathbf{G}_{4}$ & $0.61(4.42)^{\mathrm{efg}}$ & $3.27(10.40)^{\mathrm{d}}$ & 63.20 & $9.80^{\mathrm{ab}}$ & 3.85 & $94.33^{\mathrm{g}}$ \\
\hline $\mathbf{T}_{2} \mathbf{G}_{5}$ & $0.45(3.83)^{\mathrm{fg}}$ & $3.47(10.69)^{\mathrm{d}}$ & 61.47 & $7.80^{\mathrm{cd}}$ & 3.81 & $90.33^{\mathrm{g}}$ \\
\hline $\mathbf{T}_{3} \mathbf{G}_{1}$ & $36.39(37.09)^{\mathrm{a}-\mathrm{c}}$ & $76.38(60.94)^{\mathrm{ab}}$ & 60.54 & $8.19^{b-d}$ & 3.65 & $137.67^{f}$ \\
\hline $\mathbf{T}_{3} \mathbf{G}_{2}$ & $36.45(37.09)^{\mathrm{ef}}$ & $72.81(58.61)^{\mathrm{d}}$ & 63.47 & $8.23^{b-d}$ & 3.61 & $155.00^{\text {ef }}$ \\
\hline $\mathbf{T}_{\mathbf{3}} \mathbf{G}_{\mathbf{3}}$ & $0.95(5.59)^{\mathrm{a}-\mathrm{c}}$ & $3.83(11.28)^{b c}$ & 60.15 & $7.75^{\mathrm{cd}}$ & 3.67 & $202.33^{\mathrm{cd}}$ \\
\hline $\mathbf{T}_{3} \mathbf{G}_{4}$ & $0.66(4.64)^{\mathrm{e}-\mathrm{g}}$ & $3.71(11.09)^{\mathrm{d}}$ & 53.51 & $7.95^{\mathrm{cd}}$ & 3.49 & $238.00^{b}$ \\
\hline $\mathbf{T}_{3} \mathbf{G}_{5}$ & $0.27(2.98)^{\mathrm{g}}$ & $3.64(10.92)^{\mathrm{d}}$ & 59.56 & $8.36^{\mathrm{b}-\mathrm{d}}$ & 3.77 & $236.00^{\mathrm{bc}}$ \\
\hline $\mathbf{T}_{4} \mathbf{G}_{1}$ & $37.68(37.83)^{\mathrm{ab}}$ & $80.89(64.06)^{\mathrm{a}}$ & 59.49 & $6.04^{\mathrm{e}}$ & 3.01 & $53.00^{\mathrm{hi}}$ \\
\hline $\mathbf{T}_{4} \mathbf{G}_{2}$ & $38.54(38.35)^{\mathrm{a}}$ & $68.50(56.04)^{d}$ & 61.11 & $5.35^{\mathrm{e}}$ & 3.03 & $43.33^{i}$ \\
\hline $\mathbf{T}_{4} \mathbf{G}_{3}$ & $1.33(6.59)^{\mathrm{e}}$ & $4.16(11.76)^{\mathrm{c}}$ & 56.47 & $8.53^{b-d}$ & 2.87 & $72.00^{g-i}$ \\
\hline $\mathbf{T}_{4} \mathbf{G}_{4}$ & $1.03(5.80)^{\mathrm{ef}}$ & $4.46(12.19)^{d}$ & 55.77 & $9.47^{\mathrm{a}-\mathrm{c}}$ & 2.62 & $95.67^{g}$ \\
\hline $\mathbf{T}_{4} \mathbf{G}_{5}$ & $0.58(4.30)^{\mathrm{efg}}$ & $3.85(11.31)^{\mathrm{d}}$ & 60.54 & $8.57^{\mathrm{a}-\mathrm{d}}$ & 2.64 & $89.00^{\mathrm{g}}$ \\
\hline S. Em \pm & 0.75 & 1.21 & 2.62 & 0.54 & 0.12 & 10.95 \\
\hline LSD@ 5\% & 2.14 & NS & NS & 1.54 & NS & 31.34 \\
\hline
\end{tabular}

DAS:Days after sowing

*Arc sine values

DMRT-Alphabets in the column followed by the same letter do not differ significantly 
Table.2 Influence of nutrients on yield and yield components at harvest in susceptible and resistant soybean genotypes

\begin{tabular}{|c|c|c|c|c|c|}
\hline Treatments $(\mathrm{T})$ & $\begin{array}{l}\text { No. of pods } \\
\text { Plant }^{-1}\end{array}$ & $\begin{array}{l}\text { Seed yield } \\
\left(\mathrm{g}_{\text {plant }}^{-1}\right)\end{array}$ & $\begin{array}{l}\text { Seeds per pod } \\
\quad \text { (Nos.) }\end{array}$ & $\begin{array}{c}\text { Test } \\
\text { weight }\end{array}$ & $\begin{array}{l}\text { Seed yield } \\
\left(\mathrm{q} \mathrm{ha}{ }^{-1}\right)\end{array}$ \\
\hline $\mathrm{MnSO}_{4} @ 0.3 \%\left(\mathrm{~T}_{1}\right)$ & $41.26^{\mathrm{a}}$ & $11.48^{\mathrm{a}}$ & 2.36 & $11.00^{\mathrm{a}}$ & $25.03^{\mathrm{a}}$ \\
\hline $\mathrm{K}_{2} \mathrm{SiO}_{3} @ 0.3 \%\left(\mathrm{~T}_{2}\right)$ & $39.05^{\mathrm{ab}}$ & $10.95^{\mathrm{a}}$ & 2.31 & $10.59^{\mathrm{ab}}$ & $22.18^{\mathrm{ab}}$ \\
\hline $\begin{array}{l}\mathrm{MnSO}_{4}+\mathrm{K}_{2} \mathrm{SiO}_{3} @ 0.3 \% \text { each } \\
\left(\mathrm{T}_{3}\right)\end{array}$ & $40.77^{\mathrm{a}}$ & $11.32^{\mathrm{a}}$ & 2.15 & $10.11^{b}$ & $21.42^{b}$ \\
\hline Control $\left(\mathbf{T}_{4}\right)$ & $35.12^{b}$ & $9.54^{\mathrm{b}}$ & 2.13 & $9.85^{\mathrm{b}}$ & $19.64^{b}$ \\
\hline $\mathrm{S} . \mathrm{Em} \pm$ & 1.63 & 0.41 & 0.10 & 0.28 & 1.00 \\
\hline LSD@ 5\% & 4.67 & 1.18 & NS & 0.81 & 2.87 \\
\hline \multicolumn{6}{|l|}{ Genotypes (G) } \\
\hline JS 335(G $\left.\mathbf{G}_{1}\right)$ & $32.80^{\mathrm{b}}$ & $9.87^{\mathrm{c}}$ & $2.08^{b c}$ & $9.98^{\mathrm{ab}}$ & $16.60^{\mathrm{c}}$ \\
\hline Kalitur $\left(\mathbf{G}_{2}\right)$ & $35.95^{b}$ & $10.12^{\mathrm{bc}}$ & $2.01^{\mathrm{c}}$ & $9.75^{\mathrm{b}}$ & $20.58^{b}$ \\
\hline DSb $21\left(G_{3}\right)$ & $41.47^{\mathrm{a}}$ & $11.35^{\mathrm{ab}}$ & $2.29^{\mathrm{a}-\mathrm{c}}$ & $10.82^{\mathrm{a}}$ & $23.99^{\mathrm{a}}$ \\
\hline DSb $23-2\left(G_{4}\right)$ & $43.81^{\mathrm{a}}$ & $11.02^{a-c}$ & $2.39^{\mathrm{ab}}$ & $10.94^{\mathrm{a}}$ & $25.38^{\mathrm{a}}$ \\
\hline EC $241778\left(G_{5}\right)$ & $41.23^{\mathrm{a}}$ & $11.76^{\mathrm{a}}$ & $2.42^{\mathrm{a}}$ & $10.47^{\mathrm{ab}}$ & $23.80^{\mathrm{a}}$ \\
\hline S. Em \pm & 1.82 & 0.46 & 0.11 & 0.31 & 1.12 \\
\hline LSD@ 5\% & 5.22 & 1.33 & 0.31 & 0.90 & 3.21 \\
\hline \multicolumn{6}{|l|}{ Interactions ( $\mathrm{T}$ X G) } \\
\hline $\mathbf{T}_{1} \mathbf{G}_{1}$ & 33.90 & 10.54 & $2.16^{\mathrm{ab}}$ & 10.69 & 15.60 \\
\hline $\mathbf{T}_{1} \mathbf{G}_{2}$ & 41.88 & 10.50 & $2.37^{\mathrm{ab}}$ & 9.97 & 22.20 \\
\hline $\mathbf{T}_{1} \mathbf{G}_{3}$ & 43.31 & 13.34 & $2.42^{\mathrm{ab}}$ & 11.58 & 28.39 \\
\hline $\mathbf{T}_{1} \mathbf{G}_{4}$ & 44.64 & 10.82 & $2.60^{\mathrm{a}}$ & 11.81 & 30.17 \\
\hline $\mathbf{T}_{1} \mathbf{G}_{5}$ & 42.59 & 12.21 & $2.23^{\mathrm{ab}}$ & 10.94 & 28.80 \\
\hline $\mathbf{T}_{\mathbf{2}} \mathbf{G}_{1}$ & 38.04 & 10.25 & $2.49^{\mathrm{ab}}$ & 10.56 & 18.10 \\
\hline $\mathbf{T}_{\mathbf{2}} \mathbf{G}_{2}$ & 32.99 & 10.98 & $1.79^{b c}$ & 10.09 & 22.42 \\
\hline $\mathbf{T}_{\mathbf{2}} \mathbf{G}_{\mathbf{3}}$ & 42.05 & 9.79 & $2.60^{\mathrm{a}}$ & 11.15 & 23.49 \\
\hline $\mathbf{T}_{\mathbf{2}} \mathbf{G}_{4}$ & 38.46 & 11.98 & $2.07^{\mathrm{a}-\mathrm{c}}$ & 9.81 & 24.60 \\
\hline $\mathbf{T}_{\mathbf{2}} \mathbf{G}_{5}$ & 43.73 & 11.74 & $2.60^{\mathrm{a}}$ & 11.36 & 22.27 \\
\hline $\mathbf{T}_{\mathbf{3}} \mathbf{G}_{1}$ & 33.36 & 10.35 & $1.47^{\mathrm{c}}$ & 9.55 & 16.93 \\
\hline $\mathbf{T}_{\mathbf{3}} \mathbf{G}_{2}$ & 40.99 & 10.22 & $2.06^{a-c}$ & 9.43 & 21.05 \\
\hline $\mathbf{T}_{\mathbf{3}} \mathbf{G}_{\mathbf{3}}$ & 44.03 & 11.77 & $1.96^{\mathrm{a}-\mathrm{c}}$ & 10.36 & 22.73 \\
\hline $\mathbf{T}_{\mathbf{3}} \mathbf{G}_{4}$ & 46.81 & 11.61 & $2.60^{\mathrm{a}}$ & 11.19 & 24.31 \\
\hline $\mathbf{T}_{\mathbf{3}} \mathbf{G}_{5}$ & 38.65 & 12.65 & $2.67^{\mathrm{a}}$ & 10.03 & 22.07 \\
\hline $\mathbf{T}_{4} \mathbf{G}_{1}$ & 25.89 & 8.34 & $2.18^{\mathrm{ab}}$ & 9.10 & 15.77 \\
\hline $\mathbf{T}_{4} \mathbf{G}_{2}$ & 27.94 & 8.76 & $1.82^{b c}$ & 9.49 & 16.64 \\
\hline $\mathbf{T}_{4} \mathbf{G}_{3}$ & 36.49 & 10.51 & $2.19^{\mathrm{ab}}$ & 10.18 & 21.33 \\
\hline $\mathbf{T}_{4} \mathbf{G}_{4}$ & 45.32 & 9.65 & $2.30^{\mathrm{ab}}$ & 10.96 & 22.43 \\
\hline $\mathbf{T}_{4} \mathbf{G}_{5}$ & 39.96 & 10.44 & $2.16^{\mathrm{ab}}$ & 9.54 & 22.04 \\
\hline S. Em \pm & 3.65 & 0.93 & 0.22 & 0.63 & 2.24 \\
\hline LSD@ 5\% & NS & NS & 0.59 & NS & NS \\
\hline
\end{tabular}

DMRT-Alphabets in the column followed by the same letter do not differ significantly 
Manganese sulphate applied plants recorded significantly higher leaf manganese content (213 ppm) followed by the combined application of manganese sulphate and potassium silicate (194 ppm) (Table 1). Thus, an optimum concentration of manganese in soybean avoids the disease considerably through higher activity of antioxidant enzymes like peroxidase and polyphenol oxidase and also maintains higher values of growth parameters. Among the genotypes, EC 241778 recorded significantly higher leaf manganese content (162 ppm) which was on par with DSb 23-2 (159 ppm). Susceptible genotypes Kalitur (108.3 ppm) and JS 335 had lower content of manganes with the higher PDI. The inheritant manganese was 46 per cent higher in the resistant genotypes viz., DSb 23-2, DSb 21 and EC 241778 compared to the susceptible genotypes. Similar genotypic variation for manganese concentration was noticed in soybean by Bansal and Nayyar (1990) and Sanjana (2004). It is clear from this that higher manganese in resistant types offer resistance to rust disease in soybean.

Potassium can influence the tissue hardening and stomatal opening patterns are closely related to infestation intensity (Marschner, 1995). Potassium silicate treated plants recorded significantly higher leaf potassium $(3.95 \%)$ followed by the combined foliar application of manganese sulphate and potassium silicate $(3.64 \%)$. Significantly, lower leaf potassium content was noticed in the control $(2.83 \%)$ (Table 1$)$.

Peak rust infection at peak flowering stages caused 27 per cent yield loss (Table 2). The reduction was associated with the reduction in number of pods per plant, number of seeds per plant, and 100 seed weight. Melching et al., (1989) was also of the same view as regards to effect of rust on seed yield of soybean. Manganese sulphate recorded significantly higher seed yield (25.03 q ha-1), number of pods per plant (41.26) and seed yield per plant (11.48 $\mathrm{g} \mathrm{plant}^{-1}$ ) and test weight $(11 \mathrm{~g})$ due to less severity of disease. The genotype DSb 23-2 recorded significantly higher seed yield (25.38 q ha ${ }^{-1}$ ) and number of pods per plant (43.81) which was on par with the genotype DSb 21 (23.99 $\mathrm{q} \mathrm{ha}^{-1}$ and 41.47). The genotype susceptible to rust had minimum seed yield (16.60 q ha $\left.{ }^{-1}\right)$ and number of pods per plant (32.80). As regard to test weight concerned, DSb 23-2 recorded significantly higher test weight (10.94 g) which was on par with the genotype, DSb 21 $(10.82 \mathrm{~g})$. The decrease in yield and its components under diseased situations may be due to several factors such as reduction in photosynthesis, assimilatory surface (leaf area), utilization of metabolites by pathogen or may be diversion of the metabolites for building up of secondary metabolites.

In conclusion, it can be inferred from the above discussion that manganese nutrition in soybean crop has a role in mitigating the biotic stress and improving growth thereby yield also. Hence, it is suggested to formulate manganese based combinations of fungicides and find out the efficacy of manganese in control of rust disease in soybean. Rust resistant soybean genotype DSb 23-2 is better against rust giving highest yield as compared to rest of the susceptible and resistant ones.

\section{References}

Agrios, N. G., 2005, Plant Pathology, Elsevier-Academic Press, Bombay, India. p. 24

Bansal, R. L. and Nayyar, V. K., 1990, Critical manganese deficiency level for soybean grown in ustochrepts. Fertilizer Res., 25: 153-157.

Brist, S. S. and Tripathi, A., 1987, Effect of Mn supply on growth, tissue Mn and certain phosphate compounds in 
safflower plants. Paper presented In: Nation. Symp. Micronut. Stresses Crop Plants, Pune, Maharastra, pp. 16-18.

Graham, R. D. and Rovira, A. D., 1984, A role for manganese in the resistance of wheat plants to take all. Plant soil, 78 : 441-444.

Hartman, G. L., Wang, T. C. and Tschanz, A. T., 1991, Soybean rust development and the quantitative relationship between rust severity and soybean yield. American Phytopath. Soc., 75: 596-600.

Hegde, G. M., 2001, Epidemiology, crop loss assessment and management of soybean rust in Karnataka. Ph. D. Thesis, Univ. Agric. Sci., Dharwad, Karnataka (India).

Hema, M., 2001, Effect of nutrients on rust resistance in soybean. M. Sc. (Agri) Thesis, Univ. Agric. Sci., Dharwad, Karnataka (India).

Jones, O. P., Hillore, S. D. and Ramesh, A., 1998, Integrated micronutrient management in soybean. J. Oilseeds Res., 17 (2): 370-372.

Kumudini, S., Godoy, C. V., Board, J. E., Omielan, J. and Tollenaar, M., 2008, Mechanisms involved in soybean rustinduced yield reduction. Crop Sci., 48: 234-241.

Marschner, H., 1995, Mineral Nutrition of Higher Plants. Academic Press, London, UK., pp. 889-890.

Mayee, C. D. and Datar, V. V., 1986,
Phytopathometry. Tech. Bull. No.1 Marathwad Agric. Univ., Parbhani,

Melching, J. S., Dowler, W. M., Koogle, D. L. and Royer, M. H., 1989, Effect of duration, frequency, and temperature of leaf wetness period on soybean rust. Plant Dis., 73: 117-122.

Morgan, P. W., Taylor, D. M. and Joham, H. E., 1976, Manipulation of IAAoxidase activity and auxin deficiency symptoms in intact cotton plants with manganese nutrition. Physiol. Plantarum, 37: 149-156

Piper, C. V., 1914, The name of the soybean: a chapter in its botanical history. $J$. American Soci. Agro., 6: 75-84.

Sanjana, K., Koti, R. V., Patil, P. V., Fakrudin, B. and Basavraj, B., 2005, Effect of manganese and boron on rust incidence, dry matter, production and yield of soybean. Karnataka J. Agric. Sci., 18 (4): 1081-1083.

Singh, H. and Thapliyal, P. N., 1977, Some studies on the soybean rust caused by Phakopsora pachyrhizi. Indian $J$. Mycol. Plant. Patho., 7: 27-31.

Tandon, H. L. S., 1998, Methods of Analysis of Soils, Plants, Water and Fertilizers. Fert. Dev. Consul. Org., 31: 9-16.

Vidhyasekaran, P., 2004, Concise encyclopaedia of plant pathology, The Haworth Reference Press, Binghamton, New York. USA, p. 619.

Wheeler, B. E. J., 1969, An Introduction to Plant Disease. John Willey and Sons Ltd., London, p. 301.

\section{How to cite this article:}

Akshatha, S.S. and Koti, R.V. 2018. Effect of Foliar Application of Manganese and Potassium on Rust Susceptible and Resistant Soybean Genotypes. Int.J.Curr.Microbiol.App.Sci. 7(07): 1037-1043. doi: https://doi.org/10.20546/ijcmas.2018.707.126 